\title{
ICT Impact on ISB of Users in State Agricultural University Libraries in Karnataka: A Study
}

\author{
G. Kiran Kumar \\ Assistant Librarian, University Library, \\ University of Agricultural Sciences, Dharwad-580005 \\ kiranmyslibphd@gmail.com
}

\begin{abstract}
This study investigates the Information and Communication Technology impact on Information Seeking Behaviors of users in State Agricultural University libraries in Karnataka. For the present study a well structured questionnaire has been formulated and distributed among the postgraduate students, research scholars and faculty members of Agricultural Universities in Karnataka in order to ascertain the impact of information communication technology on information seeking behaviors of users i.e. library visit, time spent on ISB activities, problems faced while seeking information, purposes of seeking information, rating of factors necessitating to seek information regularly, access to e-resources available in Digital Libraries, opinion about necessity of training for using electronic resources and preference of use of information resources. The findings of the study would put light on the important data and insight into the current state of practices of users towards impact of ICT on ISB. The outcome and suggestions of the study would be beneficial for them to take appropriate measures to improve their information seeking pattern.
\end{abstract}

Keywords: Information and Communication Technology, Information Seeking Behavior, Agricultural University Libraries, Information Seeking Pattern.

\section{INTRODUCTION}

The information seeking behavior of users especially in developing countries has been a significant and eventful issue from last few decades, libraries have become increasingly aware of the revolutionary impact of developments in information and communication technology on their key functions. The application of ICT facilitates easy and instantaneous access to information. It provides opportunities for libraries and information centers to widen the scope of their resources and services and to increase their significance within the organization they serve. This study investigates the impact of information and communication technology on information seeking behavior of agricultural scientists, teaching faculty, research scholars and postgraduate students, for their course work and research activities, the extent to which they use the library, types of services utilized, awareness and use of the electronic library.

The Indian Council of Agricultural Research, the controlling agency for agricultural universities in India, has implemented a special project with the assistance of the World Bank to modernize the Library and Information Systems of all agricultural universities and the ICAR Institutes in the country. The project included special funding, technical assistance and training for the library staff, teachers, research scholars and students. The university libraries have automated most of their operations and many of them could develop digital libraries of theses. The users of agricultural university libraries are to gather information from various means and methods, a better understanding is required to know the needs, kinds of resources and ICT based services that could make education and research work more effective and efficient. The overwhelming ICT preferences are to ask the questions and seek the information by e-mail, telephone/mobile phone, online chat, discussion forum, messenger, 
Web blogs, Wiki, Television, Radio, Computer Mediated Conferencing, Video Conferencing and other collaborative working tools particularly social networks on the Internet greatly facilitate information transfer and sharing from one to one as well as one to many. The present study covers postgraduate students, research scholars and faculty members of five Agricultural Sciences Universities in Karnataka i.e. University of Agricultural Sciences, Dharwad, University of Agricultural Sciences, Bengaluru, University of Agricultural \& Horticultural Sciences, Shivamogga, University of Horticultural Sciences, Bagalkot and University of Agricultural Sciences, Raichur.

\section{Objectives of the Study}

The present study is an attempt to find out the ICT Impact on ISB of Users in State Agricultural University Libraries in Karnataka. The main objectives of the study are:

i. To examine the extent of Information Seeking Behavior of library users of Agricultural Universities in Karnataka in the changing digital era.

ii. To identify types and range of electronic information resources used by academicians in the field of agricultural sciences and also to determine the level and awareness about seeking information.

iii. To study the purpose of information seeking and hindrance faced by the library users of Agricultural Universities in Karnataka.

iv. To know the extent of access to e-resources available in Digital Libraries and to know the opinion about necessity of training for using ICT based electronic resources.

\section{Methodology}

The questionnaire method was used for the present study to collect the necessary data, keeping in view the objectives of the study. Total of 1682 questionnaire were distributed among the postgraduate students, research scholars and members of faculty of Agricultural Sciences Universities in Karnataka, of which 1351 filled-up questionnaire were received back consisting of $80.32 \%$ responses. The highest numbers of questionnaire have been received from University of Agricultural Sciences, Dharwad with 401 (29.68\%) responses, followed by University of Agricultural Sciences, Bangalore with 366 (27.09\%) responses, University of Agricultural Sciences, Raichur with 248 (18.35\%) responses, University of Agricultural and Horticultural Sciences, Shivamogga with 169 (12.50\%) responses and University of Horticultural Sciences, Bagalkot with $167(12.36 \%)$ responses. In addition to the questionnaire method, interview schedule and observation method were also used to collect required information.

\section{Analysis and Interpretation of Data}

The data was collected by different methods were analyzed and interpreted and same presented in the following tables.

\section{1 .Gender Wise Distribution}

The gender wise distribution of the respondents under the study has been shown in Table-1. The Table- 1 shows that out of the 1351 total respondents, 793 (58.69\%) are 'Male' and the remaining 558 (41.30\%) are 'Female'.

\section{Table-1: Gender Wise Distribution}

\begin{tabular}{|c|c|c|c|c|}
\hline Gender & $\begin{array}{l}\text { PG Students } \\
(\mathrm{N}=743)\end{array}$ & $\begin{array}{l}\text { Research } \quad \text { Scholars } \\
(\mathrm{N}=282)\end{array}$ & $\begin{array}{l}\text { Faculty } \\
\text { Members (N=326) }\end{array}$ & $\begin{array}{l}\text { Total } \\
(\mathrm{N}=1351)\end{array}$ \\
\hline Male & $412(55.45)$ & $158(56.02)$ & $223(68.40)$ & 793 (58.69) \\
\hline Female & $331(44.54)$ & $124(43.97)$ & $103(31.59)$ & $558(41.30)$ \\
\hline
\end{tabular}


The Table-1 also depicts that out of 743 postgraduate students, 412 (55.45\%) are 'Male' and remaining 331 (44.54\%) are 'Female'. Among the 282 research scholars, 158 (56.02\%) are 'Male' and remaining $124(43.97 \%)$ are 'Female'. Out of 326 faculty members, 223 (68.40\%) are 'Male' and remaining 103 (31.59\%) are 'Female'.

\subsection{Designation Wise Distribution}

The designations have been categorized as postgraduate student, research scholar and faculty. The faculty members have been further categorized as Assistant Professors, Associate Professors and Professors. The Table-2 shows the designation wise distribution of respondents in Agricultural Universities in Karnataka. About 737 (54.44\%) of respondents are Postgraduate students, followed by $343(25.38 \%)$ are Research Scholars, 145 (10.73\%) are Assistant Professors, 73 (05.40\%) are Professors and $53(03.92 \%)$ are Associate Professors. The Table-2 also shows in detail university wise distribution of respondents.

Table-2: Designation Wise Distribution

\begin{tabular}{|c|c|c|c|c|c|c|}
\hline \multirow[b]{2}{*}{$\begin{array}{l}\text { Name of the } \\
\text { University }\end{array}$} & \multicolumn{5}{|c|}{ Designation } & \multirow[b]{2}{*}{$\begin{array}{l}\text { Total } \\
(\mathrm{N}=\mathbf{1 3 5 1})\end{array}$} \\
\hline & $\begin{array}{l}\text { UAS, } \\
\text { Dharwad } \\
(\mathrm{N}=401)\end{array}$ & $\begin{array}{l}\text { UAS, } \\
\text { Bangalore } \\
(\mathrm{N}=\mathbf{3 6 6})\end{array}$ & $\begin{array}{l}\text { UAS, } \\
\text { Raichur } \\
(\mathrm{N}=248)\end{array}$ & $\begin{array}{l}\text { UAS, } \\
\text { Shivamogga } \\
(\mathrm{N}=169)\end{array}$ & $\begin{array}{l}\text { UHS, } \\
\text { Bagalkot } \\
(\mathrm{N}=167)\end{array}$ & \\
\hline PG Student & $\begin{array}{l}229 \\
(57.10)\end{array}$ & $\begin{array}{l}167 \\
(45.62)\end{array}$ & $\begin{array}{l}132 \\
(53.22)\end{array}$ & $\begin{array}{l}107 \\
(63.31)\end{array}$ & $\begin{array}{l}102 \\
(61.07)\end{array}$ & $\begin{array}{l}737 \\
(54.55)\end{array}$ \\
\hline $\begin{array}{l}\text { Research } \\
\text { Scholar }\end{array}$ & $\begin{array}{l}103 \\
(25.68)\end{array}$ & $\begin{array}{l}92 \\
(25.13)\end{array}$ & $\begin{array}{l}68 \\
(27.41)\end{array}$ & $\begin{array}{l}39 \\
(23.07)\end{array}$ & $\begin{array}{l}41 \\
(24.55)\end{array}$ & $\begin{array}{l}343 \\
(25.38)\end{array}$ \\
\hline $\begin{array}{l}\text { Assistant } \\
\text { Professor }\end{array}$ & $\begin{array}{l}35 \\
(08.72)\end{array}$ & $\begin{array}{l}56 \\
(15.30)\end{array}$ & $\begin{array}{l}26 \\
(1.48)\end{array}$ & $\begin{array}{l}12 \\
(07.10)\end{array}$ & $\begin{array}{l}16 \\
(09.58)\end{array}$ & $\begin{array}{l}145 \\
(10.73)\end{array}$ \\
\hline $\begin{array}{l}\text { Associate } \\
\text { Professor }\end{array}$ & $\begin{array}{l}22 \\
(05.48)\end{array}$ & $\begin{array}{l}13 \\
(03.55)\end{array}$ & $\begin{array}{l}09 \\
(03.62)\end{array}$ & $\begin{array}{l}04 \\
(02.36)\end{array}$ & $\begin{array}{l}05 \\
(02.99)\end{array}$ & $\begin{array}{l}53 \\
(03.92)\end{array}$ \\
\hline Professor & $\begin{array}{l}12 \\
(02.99)\end{array}$ & $\begin{array}{l}38 \\
(10.38)\end{array}$ & $\begin{array}{l}13 \\
(05.24)\end{array}$ & $\begin{array}{l}07 \\
(04.14)\end{array}$ & $\begin{array}{l}03 \\
(01.79)\end{array}$ & $\begin{array}{l}73 \\
(05.40)\end{array}$ \\
\hline
\end{tabular}

\subsection{University Library Membership}

The Table- 3 shows the library membership registration by the postgraduate students, research scholars and faculty members. The Table-3 depicts that 1299 (96.15\%) of respondents have the university library membership and 52 (03.84\%) of respondents do not have University Library Membership.

Table-3: University Library Membership

\begin{tabular}{|l|l|l|l|l|}
\hline Opinion & $\begin{array}{l}\text { PG Students } \\
(\mathbf{N = 7 4 3})\end{array}$ & $\begin{array}{l}\text { Research Scholars } \\
(\mathbf{N = 2 8 2})\end{array}$ & $\begin{array}{l}\text { Faculty } \\
\text { Members }(\mathbf{N}=\mathbf{3 2 6})\end{array}$ & $\begin{array}{l}\text { Total } \\
(\mathbf{N}=\mathbf{1 3 5 1})\end{array}$ \\
\hline Yes & $719(96.76)$ & $276(97.87)$ & $304(93.25)$ & $1299(96.15)$ \\
\hline No & $24(03.23)$ & $06(02.12)$ & $22(06.74)$ & $52(03.84)$ \\
\hline
\end{tabular}

The Table-3 also depicts that 719 (96.76\%) of postgraduate students, $276(97.87 \%)$ of research scholars and $304(93.25 \%)$ of faculty members opine as 'Yes' i.e. having the university library membership and 24 (03.23\%) of postgraduate students, 06 $(02.12 \%)$ of research scholars and $22(06.74 \%)$ of faculty members opine as 'No' i.e. do not have the university library membership. 


\subsection{Frequency of Library Visits}

Agricultural university postgraduate students, research scholars and faculty members would like to visit their main library for using e-resources. Although, the advent of Internet has reduced the frequency of the faculty members' visit to their main library, it is assumed that still most of them prefer to go to the library at different intervals. The Table- 4 shows the frequency of visit to the library among the respondents.

The Table-4 depicts that 366 (27.09\%) of respondents visit the library 'Everyday' with mean value of 1.3798 and SD 0.65000 , followed by $305(22.57 \%)$ of respondents visit the library 'As and when need arise' with mean value of 1.7148 and SD 0.80742 , about $246(18.20 \%)$ of respondents visit the library 'Alternate days' with mean value of 1.7276 and SD $0.80496,158(11.69 \%)$ of respondents visit the library 'Twice a week' with mean value of 1.5823 and SD $0.78371,144$ (10.65\%) of respondents visit the library 'Once a week' with mean value of 2.0347 and SD 0.96377 and $132(09.77 \%)$ of respondents visit the library 'Once in a month' with mean value of 2.1894 and SD 0.92574 .

Table-4: Frequency of Library Visits

\begin{tabular}{|c|c|c|c|c|c|c|}
\hline $\begin{array}{ll}\text { Frequency } & \text { of } \\
\text { Library Visit }\end{array}$ & $\begin{array}{l}\text { PG Students } \\
(\mathrm{N}=743)\end{array}$ & $\begin{array}{l}\text { Research } \\
\text { Scholars } \\
(\mathrm{N}=\mathbf{2 8 2})\end{array}$ & $\begin{array}{l}\text { Faculty } \\
\text { Members } \\
(\mathbf{N}=326)\end{array}$ & $\begin{array}{l}\text { Total } \\
(\mathrm{N}=1351)\end{array}$ & Mean & SD \\
\hline Every day & $\begin{array}{l}261 \\
(35.12)\end{array}$ & $\begin{array}{l}71 \\
(25.17)\end{array}$ & $\begin{array}{l}34 \\
(10.42)\end{array}$ & $\begin{array}{l}366 \\
(27.09)\end{array}$ & 1.3798 & 0.65000 \\
\hline Alternate day & $\begin{array}{l}122 \\
(16.41)\end{array}$ & $\begin{array}{l}69 \\
(24.46)\end{array}$ & $\begin{array}{l}55 \\
(16.87)\end{array}$ & $\begin{array}{l}246 \\
(18.20)\end{array}$ & 1.7276 & 0.80496 \\
\hline Once a week & $\begin{array}{l}64 \\
(08.61)\end{array}$ & $\begin{array}{l}11 \\
(03.90)\end{array}$ & $\begin{array}{l}69 \\
(21.16)\end{array}$ & $\begin{array}{l}144 \\
(10.65)\end{array}$ & 2.0347 & 0.96377 \\
\hline Twice a week & $\begin{array}{l}95 \\
(12.78)\end{array}$ & $\begin{array}{l}34 \\
(12.05)\end{array}$ & $\begin{array}{l}29 \\
(08.89)\end{array}$ & $\begin{array}{l}158 \\
(11.69)\end{array}$ & 1.5823 & 0.78371 \\
\hline Once a month & $\begin{array}{l}46 \\
(06.19)\end{array}$ & $\begin{array}{l}15 \\
(05.31)\end{array}$ & $\begin{array}{l}71 \\
(21.77)\end{array}$ & $\begin{array}{l}132 \\
(09.77)\end{array}$ & 2.1894 & 0.92574 \\
\hline $\begin{array}{l}\text { As and when need } \\
\text { arise }\end{array}$ & $\begin{array}{l}155 \\
(20.86)\end{array}$ & $\begin{array}{l}82 \\
(29.07)\end{array}$ & $\begin{array}{l}68 \\
(20.85)\end{array}$ & $\begin{array}{l}305 \\
(22.57)\end{array}$ & 1.7148 & 0.80742 \\
\hline
\end{tabular}

The Table-4 also depicts that 261 (35.12\%) of postgraduate students visit the library 'Everyday', followed by 82 (29.07\%) of research scholars visit the library 'As and when need arise' and $71(21.77 \%)$ of faculty members visit the library 'Once a month'.

\subsection{Time Spent for ISB activities in the Library}

The time spent per week for ISB activities in the library has been summarized in Table-5. The Table-5 depicts that 382 (28.27\%) of respondents spent ' $3-4$ Hours' in a week for ISB activities in the library with mean value of 1.6021 and SD 0.80926 , followed by $308(22.79 \%)$ of respondents spent ' $1-2$ Hours' in a week with mean value of 2.0649 and SD 0.93902 , $239(17.68 \%)$ of respondents spent '7-8 Hours' in a week with mean value of 1.4059 and SD $0.68487,228(16.68 \%)$ of respondents spent '5-6 Hours' in a week with mean value of 1.7982 and SD 0.82023 and 194 (14.35\%) of respondents spent 'Above 9 Hours' in a week for ISB activities in the library with mean value of 1.5000 and SD 0.64583. 
ICT Impact on ISB of Users in State Agricultural University Libraries in Karnataka: A Study

Table-5: Time Spent for ISB activities in the Library

\begin{tabular}{|c|c|c|c|c|c|c|}
\hline \begin{tabular}{l}
\multicolumn{2}{l}{ Time Spent } \\
(Hours Per \\
Week)
\end{tabular} & $\begin{array}{l}\text { PG Students } \\
(\mathrm{N}=743)\end{array}$ & $\begin{array}{l}\text { Research } \\
\text { Scholars } \\
(\mathrm{N}=\mathbf{2 8 2})\end{array}$ & $\begin{array}{l}\text { Faculty } \\
\text { Members } \\
(\mathrm{N}=326)\end{array}$ & $\begin{array}{l}\text { Total } \\
(\mathrm{N}=1351)\end{array}$ & Mean & SD \\
\hline $1-2$ & $\begin{array}{l}126 \\
(16.95)\end{array}$ & $\begin{array}{l}36 \\
(12.76)\end{array}$ & $\begin{array}{l}146 \\
(44.78)\end{array}$ & $\begin{array}{l}308 \\
(22.79)\end{array}$ & 2.0649 & 0.93902 \\
\hline $3-4$ & $\begin{array}{l}231 \\
(31.09)\end{array}$ & $\begin{array}{l}72 \\
(25.53)\end{array}$ & $\begin{array}{l}79 \\
(24.23)\end{array}$ & $\begin{array}{l}382 \\
(28.27)\end{array}$ & 1.6021 & 0.80926 \\
\hline $5-6$ & $\begin{array}{l}104 \\
(13.99)\end{array}$ & $\begin{array}{l}66 \\
(23.40)\end{array}$ & $\begin{array}{l}58 \\
(17.79)\end{array}$ & $\begin{array}{l}228 \\
(16.87)\end{array}$ & 1.7982 & 0.82023 \\
\hline $7-8$ & $\begin{array}{l}169 \\
(22.74)\end{array}$ & $\begin{array}{l}43 \\
(15.24)\end{array}$ & $\begin{array}{l}27 \\
(08.28)\end{array}$ & $\begin{array}{l}239 \\
(17.68)\end{array}$ & 1.4059 & 0.68487 \\
\hline Above 9 & $\begin{array}{l}113 \\
(15.20)\end{array}$ & $\begin{array}{l}65 \\
(23.04)\end{array}$ & $\begin{array}{l}16 \\
(04.90)\end{array}$ & $\begin{array}{l}194 \\
(14.35)\end{array}$ & 1.5000 & 0.64583 \\
\hline
\end{tabular}

The Table-5 also depicts that 231 (31.09\%) of postgraduate students spent ' $3-4$ Hours' in a week for ISB activities in the library, 72 (25.53\%) of research scholars spent ' 3 -4 Hours' in a week for ISB activities in the library and 146 (44.78\%) of faculty members spent ' $1-2$ Hours' in a week for ISB activities in the library.

\subsection{Problems Faced while Seeking Information}

The problem faced while seeking information by the respondents has been summarized in Table-6.The Table- 6 depicts that $539(39.90 \%)$ of respondents face problem because of information materials are old, 525 (38.86\%) of respondents face problem due to delay and time consuming to search printed information resources in the library, $452(33.46 \%)$ face problem because of non availability of materials, $383(28.35 \%)$ information scattered in too many sources, $362(26.79 \%)$ information is too vast, $331(24.50 \%)$ do not know how to use the information retrieval tools, $188(13.92 \%)$ don't know the sources available in the library and $171(12.66 \%)$ of respondents face problem because of library staff are unwilling to provide services.

Table-6: Problems Faced while Seeking Information

\begin{tabular}{|c|c|c|c|c|}
\hline Problems & $\begin{array}{l}\text { PG Students } \\
(\mathrm{N}=743)\end{array}$ & $\begin{array}{l}\text { Research } \\
\text { Scholars } \\
(\mathrm{N}=\mathbf{2 8 2})\end{array}$ & $\begin{array}{l}\text { Faculty } \\
\text { Members }(\mathrm{N}=326)\end{array}$ & $\begin{array}{l}\text { Total } \\
(\mathrm{N}=1351)\end{array}$ \\
\hline Materials are not available & $\begin{array}{l}322 \\
(43.34)\end{array}$ & $\begin{array}{l}74 \\
(26.24)\end{array}$ & $\begin{array}{l}56 \\
(17.18)\end{array}$ & $\begin{array}{l}452 \\
(33.46)\end{array}$ \\
\hline Don't know the sources available in the library & $\begin{array}{l}129 \\
(17.36)\end{array}$ & $\begin{array}{l}36 \\
(12.77)\end{array}$ & $\begin{array}{l}23 \\
(07.06)\end{array}$ & $\begin{array}{l}188 \\
(13.92)\end{array}$ \\
\hline $\begin{array}{l}\text { Delay and time consuming to search printed } \\
\text { information resources in the library }\end{array}$ & $\begin{array}{l}390 \\
(52.49)\end{array}$ & $\begin{array}{l}89 \\
(31.56)\end{array}$ & $\begin{array}{l}46 \\
(14.11)\end{array}$ & $\begin{array}{l}525 \\
(38.86)\end{array}$ \\
\hline Information is too vast & $\begin{array}{l}112 \\
(15.07)\end{array}$ & $\begin{array}{l}119 \\
(42.20)\end{array}$ & $\begin{array}{l}131 \\
(40.18)\end{array}$ & $\begin{array}{l}362 \\
(26.79)\end{array}$ \\
\hline Information materials are old & $\begin{array}{l}217 \\
(29.21)\end{array}$ & $\begin{array}{l}121 \\
(42.91)\end{array}$ & $\begin{array}{l}201 \\
(61.66)\end{array}$ & $\begin{array}{l}539 \\
(39.90)\end{array}$ \\
\hline
\end{tabular}




\begin{tabular}{|c|c|c|c|c|}
\hline $\begin{array}{l}\text { Do not know how to use the information } \\
\text { retrieval tools }\end{array}$ & $\begin{array}{l}206 \\
(27.73)\end{array}$ & $\begin{array}{l}56 \\
(19.86)\end{array}$ & $\begin{array}{l}69 \\
(21.17)\end{array}$ & $\begin{array}{l}331 \\
(24.50)\end{array}$ \\
\hline Information scattered in too many sources & $\begin{array}{l}164 \\
(22.07)\end{array}$ & $\begin{array}{l}103 \\
(36.52)\end{array}$ & $\begin{array}{l}116 \\
(35.58)\end{array}$ & $\begin{array}{l}383 \\
(28.35)\end{array}$ \\
\hline Library staff are unwilling to provide services & $\begin{array}{l}88 \\
(11.84)\end{array}$ & $\begin{array}{l}62 \\
(21.99)\end{array}$ & $\begin{array}{l}21 \\
(06.44)\end{array}$ & $\begin{array}{l}171 \\
(12.66)\end{array}$ \\
\hline
\end{tabular}

Note: Figures in parentheses indicate percentage and because of multiple choice options the percentage is exceeded to more than $100 \%$.

The Table-6 also depicts that 390 (52.49\%) of postgraduate students face problem because due to delay and time consuming to search printed information resources in the library, $121(42.91 \%)$ of research scholars and $201(61.66 \%)$ of faculty members face problem because of information materials are old.

\subsection{Purposes of Seeking Information}

The purpose of seeking information by the respondents has been summarized in Table-7.The Table-7 depicts that 1073 (79.42\%) of respondents seek information for the purpose of research work, followed by $898(66.47 \%)$ of respondents seek information for self improvement, 851 (62.99\%) for exam purpose, 834 (61.73\%) for continuing education, 808 (59.81\%) to acquire and update knowledge in the field, 758 (56.11\%) to prepare project proposal,701 (51.89\%) for teaching, $696(51.52 \%)$ to maintain professional competence, 687 (50.85\%) of respondents seek information for general awareness.

\section{Table-7: Purposes of Seeking Information}

\begin{tabular}{|c|c|c|c|c|}
\hline Purpose & $\begin{array}{l}\text { PG Students } \\
(\mathrm{N}=\mathbf{7 4 3})\end{array}$ & $\begin{array}{l}\text { Research } \\
\text { Scholars } \\
(\mathbf{N = 2 8 2})\end{array}$ & $\begin{array}{l}\text { Faculty } \\
\text { Members } \\
(\mathrm{N}=326)\end{array}$ & $\begin{array}{l}\text { Total } \\
(\mathrm{N}=1351)\end{array}$ \\
\hline For teaching. & $\begin{array}{l}226 \\
(30.42)\end{array}$ & $\begin{array}{l}188 \\
(66.67)\end{array}$ & $\begin{array}{l}287 \\
(88.04)\end{array}$ & $\begin{array}{l}701 \\
(51.89)\end{array}$ \\
\hline For research work. & $\begin{array}{l}501 \\
(67.43)\end{array}$ & $\begin{array}{l}271 \\
(96.10)\end{array}$ & $\begin{array}{l}301 \\
(92.33)\end{array}$ & $\begin{array}{l}1073 \\
(79.42)\end{array}$ \\
\hline To prepare project proposal. & $\begin{array}{l}289 \\
(38.90)\end{array}$ & $\begin{array}{l}226 \\
(80.14)\end{array}$ & $\begin{array}{l}243 \\
(74.54\end{array}$ & $\begin{array}{l}758 \\
(56.11)\end{array}$ \\
\hline For self improvement. & $\begin{array}{l}388 \\
(52.22)\end{array}$ & $\begin{array}{l}204 \\
(72.34)\end{array}$ & $\begin{array}{l}306 \\
(93.87)\end{array}$ & $\begin{array}{l}898 \\
(66.47)\end{array}$ \\
\hline To acquire and update knowledge in the field. & $\begin{array}{l}321 \\
(43.20)\end{array}$ & $\begin{array}{l}199 \\
(70.57)\end{array}$ & $\begin{array}{l}288 \\
(88.34)\end{array}$ & $\begin{array}{l}808 \\
(59.81)\end{array}$ \\
\hline For exam purpose. & $\begin{array}{l}456 \\
(61.37)\end{array}$ & $\begin{array}{l}221 \\
(78.37)\end{array}$ & $\begin{array}{l}174 \\
(53.37)\end{array}$ & $\begin{array}{l}851 \\
(62.99)\end{array}$ \\
\hline For general awareness. & $\begin{array}{l}290 \\
(39.03)\end{array}$ & $\begin{array}{l}166 \\
(58.87)\end{array}$ & $\begin{array}{l}231 \\
(70.86)\end{array}$ & $\begin{array}{l}687 \\
(50.85)\end{array}$ \\
\hline For continuing education. & $\begin{array}{l}380 \\
(51.14)\end{array}$ & $\begin{array}{l}209 \\
(74.11)\end{array}$ & $\begin{array}{l}245 \\
(75.15)\end{array}$ & $\begin{array}{l}834 \\
(61.73)\end{array}$ \\
\hline To maintain professional competence. & $\begin{array}{l}133 \\
(17.90)\end{array}$ & $\begin{array}{l}224 \\
(79.43)\end{array}$ & $\begin{array}{l}288 \\
(88.34)\end{array}$ & $\begin{array}{l}696 \\
(51.52)\end{array}$ \\
\hline
\end{tabular}


Note: Figures in parentheses indicate percentage and because of multiple choice options the percentage is exceeded to more than $100 \%$.

The Table-7 depicts that $501(67.43 \%)$ of postgraduate students and 271 (96.10\%) of research scholars seek information for the purpose of research work and $306(93.87 \%)$ of faculty members seek information for the purpose of self improvement.

\subsection{Rating of Factors Necessitating to Seek Information Regularly.}

The rating of factors necessitating to seek information regularly has been summarized in Table-8.The Table- 8 depicts that 562 $(41.60 \%)$ of respondents opine the factor of research thrust in your own field as 'Not Necessitate', followed by 352 (26.05\%) of respondents opine the factor of Self satisfaction/self improvement as 'Highly Necessitate', 882 (65.28\%) of respondents opine the factor of need to qualify for further promotion as 'Not Necessitate', $336(24.87 \%)$ of respondents opine the factor of desire to gain recognition in the field as 'Occasionally Necessitate', $402(29.76 \%)$ of respondents opine the factor of guiding researchers as 'Rarely Necessitate', 380 (28.13\%) of respondents opine the factor of preparation for class lectures as 'Occasionally Necessitate', 403 (29.83\%) of respondents opine the factor of writing research papers as 'Occasionally Necessitate' and 427 (31.61\%) of respondents opine the factor of preparation for competitive exams as 'Rarely Necessitate'.

Table-8: Rating of Factors Necessitating to Seek Information Regularly.

\begin{tabular}{|c|c|c|c|c|c|}
\hline \multirow[b]{2}{*}{ Factors } & \multicolumn{5}{|c|}{ Total $(\mathbf{N}=1351)$} \\
\hline & 1 & 2 & 3 & 4 & 5 \\
\hline Research thrust in your own field. & $\begin{array}{l}562 \\
(41.60)\end{array}$ & $\begin{array}{l}199 \\
(14.73)\end{array}$ & $\begin{array}{l}204 \\
(15.10)\end{array}$ & $\begin{array}{l}176 \\
(13.03)\end{array}$ & $\begin{array}{l}210 \\
(15.54)\end{array}$ \\
\hline Self satisfaction/self improvement. & $\begin{array}{l}151 \\
(11.18)\end{array}$ & $\begin{array}{l}297 \\
(21.98)\end{array}$ & $\begin{array}{l}332 \\
(24.57)\end{array}$ & $\begin{array}{l}219 \\
(16.21)\end{array}$ & $\begin{array}{l}352 \\
(26.05)\end{array}$ \\
\hline Need to qualify for further promotion. & $\begin{array}{l}882 \\
(65.28)\end{array}$ & $\begin{array}{l}112 \\
(08.29)\end{array}$ & $\begin{array}{l}156 \\
(11.55)\end{array}$ & $\begin{array}{l}107 \\
(07.92)\end{array}$ & $\begin{array}{l}94 \\
(06.96)\end{array}$ \\
\hline Desire to gain recognition in the field. & $\begin{array}{l}174 \\
(12.88)\end{array}$ & $\begin{array}{l}291 \\
(21.54)\end{array}$ & $\begin{array}{l}336 \\
(24.87)\end{array}$ & $\begin{array}{l}251 \\
(18.58)\end{array}$ & $\begin{array}{l}299 \\
(22.13)\end{array}$ \\
\hline Guiding researchers. & $\begin{array}{l}386 \\
(28.57)\end{array}$ & $\begin{array}{l}402 \\
(29.76)\end{array}$ & $\begin{array}{l}136 \\
(10.07)\end{array}$ & $\begin{array}{l}309 \\
(22.87)\end{array}$ & $\begin{array}{l}118 \\
(08.73)\end{array}$ \\
\hline Preparation for class lectures. & $\begin{array}{l}146 \\
(10.81)\end{array}$ & $\begin{array}{l}221 \\
(16.36)\end{array}$ & $\begin{array}{l}380 \\
(28.13)\end{array}$ & $\begin{array}{l}266 \\
(19.69)\end{array}$ & $\begin{array}{l}338 \\
(25.02)\end{array}$ \\
\hline Writing research paper. & $\begin{array}{l}112 \\
(08.29)\end{array}$ & $\begin{array}{l}369 \\
(27.31)\end{array}$ & $\begin{array}{l}403 \\
(29.83)\end{array}$ & $\begin{array}{l}219 \\
(16.21)\end{array}$ & $\begin{array}{l}248 \\
(18.36)\end{array}$ \\
\hline For preparation for competitive exam. & $\begin{array}{l}301 \\
(22.28)\end{array}$ & $\begin{array}{l}427 \\
(31.61)\end{array}$ & $\begin{array}{l}226 \\
(16.73)\end{array}$ & $\begin{array}{l}186 \\
(13.77)\end{array}$ & $\begin{array}{l}211 \\
(15.62)\end{array}$ \\
\hline $\begin{array}{l}\text { Note: 1-Not Necessitate, 2-Rarely Ne } \\
\text { 4-Frequently Necessitates, 5-Highly }\end{array}$ & $\begin{array}{l}\text { itates, } \\
\text { essitate }\end{array}$ & ionall & ssitates, & & \\
\hline
\end{tabular}

\subsection{Access to E-Resources Available in Digital Libraries}

The access to e-resources available in Digital Libraries by the respondents has been summarized in Table-9.The Table-9 depicts that $990(73.27 \%)$ of respondents opine as 'Yes' i.e. they access to e-resources available in Digital Libraries and 361 $(26.72 \%)$ of respondents opine as 'No' i.e. they do not access to e-resources available in Digital Libraries. 
Table-9: Access to E-Resources Available in Digital Libraries

\begin{tabular}{|c|c|c|c|c|}
\hline Opinion & $\begin{array}{l}\text { PG Students } \\
(\mathrm{N}=743)\end{array}$ & $\begin{array}{l}\text { Research } \quad \text { Scholars } \\
(\mathrm{N}=282)\end{array}$ & $\begin{array}{l}\text { Faculty } \\
\text { Members }(\mathrm{N}=326)\end{array}$ & $\begin{array}{l}\text { Total } \\
(\mathbf{N}=1351)\end{array}$ \\
\hline Yes & $\begin{array}{l}556 \\
(74.83)\end{array}$ & $\begin{array}{l}211 \\
(74.82)\end{array}$ & $\begin{array}{l}223 \\
(68.40)\end{array}$ & $\begin{array}{l}990 \\
(73.27)\end{array}$ \\
\hline No & $\begin{array}{l}187 \\
(25.16)\end{array}$ & $\begin{array}{l}71 \\
(25.17)\end{array}$ & $\begin{array}{l}103 \\
(31.59)\end{array}$ & $\begin{array}{l}361 \\
(26.72)\end{array}$ \\
\hline
\end{tabular}

The Table-9 also depicts that $556(74.83 \%)$ of postgraduate students, 211 (74.82\%) of research scholars and $223(68.40 \%)$ of faculty members opine as 'Yes' i.e. they access to e-resources available in Digital Libraries and 187 (25.16\%) of postgraduate students, $71(25.17 \%)$ of research scholars and $103(31.59 \%)$ of faculty members opine as 'No' i.e. they do not access to e-resources available in Digital Libraries.

\subsection{Opinion about Necessity of Training for Using ICT Based Electronic Resources}

The opinion about necessity of training for using ICT based electronic resources by the respondents has been summarized in Table-10.The Table-10 depicts that $636(47.07 \%)$ of respondents opine necessity of training for using ICT based electronic resources as 'Very Important' with mean value 1.8302 and SD 0.87093 , followed by 561 (41.52\%) of respondents opine necessity of training for using ICT based electronic resources as 'Important' with mean value 1.5579 and SD 0.78190 and 154 $(11.39 \%)$ of respondents opine necessity of training for using ICT based electronic resources as 'Not Required' with mean value 1.6039 and SD 0.77896.

Table-10: Opinion about Necessity of Training for Using ICT Based Electronic Resources

\begin{tabular}{|c|c|c|c|c|c|c|}
\hline Opinion & $\begin{array}{l}\text { PG Students } \\
(\mathrm{N}=743)\end{array}$ & $\begin{array}{l}\text { Research } \\
\text { Scholars } \\
(\mathbf{N}=\mathbf{2 8 2})\end{array}$ & $\begin{array}{l}\text { Faculty } \\
\text { Members } \\
(\mathrm{N}=326)\end{array}$ & $\begin{array}{l}\text { Total } \\
(\mathrm{N}=1351)\end{array}$ & Mean & SD \\
\hline Very Important & $\begin{array}{l}304 \\
(40.91)\end{array}$ & $\begin{array}{l}136 \\
(48.22)\end{array}$ & $\begin{array}{l}196 \\
(60.12)\end{array}$ & $\begin{array}{l}636 \\
(47.07)\end{array}$ & 1.8302 & 0.87093 \\
\hline Important & $\begin{array}{l}350 \\
(47.10)\end{array}$ & $\begin{array}{l}109 \\
(38.65)\end{array}$ & $\begin{array}{l}102 \\
(31,28)\end{array}$ & $\begin{array}{l}561 \\
(41.52)\end{array}$ & 1.5579 & 0.78190 \\
\hline Not Required & $\begin{array}{l}89 \\
(11.97)\end{array}$ & $\begin{array}{l}37 \\
(13.12)\end{array}$ & $\begin{array}{l}28 \\
(08.58)\end{array}$ & $\begin{array}{l}154 \\
(11.39)\end{array}$ & 1.6039 & 0.77896 \\
\hline
\end{tabular}

The Table-10 also depicts that $350(47.10 \%)$ of postgraduate students opine necessity of training for using ICT based electronic resources as 'Important', followed by 136 (48.22\%) of research scholars opine necessity of training for using ICT based electronic resources as 'Very Important' and 196 (60.12\%) of faculty members opine necessity of training for using ICT based electronic resources as 'Very Important'.

\section{Recommendations}

The following recommendations are made based on the study.

- The controlling authorities like Indian Council of Agricultural Research and Department of Agricultural Research and Education should develop the infrastructural facilities to their constituent institutes like Central Agricultural Universities/ State Agricultural Universities/ ICAR Research Centers, so that the proper and effective web resources service can be utilized by the users. 
- The authorities of State Agricultural Universities should conduct training programme on Information and Communication Technology Application, Internet awareness, access of e-resources, e-books, e-journals, e-databases for the users of State Agricultural University Libraries and they should be encouraged to take part in these activities.

- The study indicates the need of orientation, training, workshop of e-resources for faculty members, research scholars and postgraduate students also.

- State Agricultural Universities should send library professionals periodically to attend conference, workshop and seminars, so as to keep themselves updated with recent technologies.

- The State Agricultural Universities in Karnataka should be provided requisite financial benefits for rendering highly technical and modern library services to the users as they demand.

- The State Agricultural Universities of Karnataka need to change their curricula focusing more on ICT and changing library environment.

\section{Conclusion}

The study provided useful insights into the impact of Information and Communication Technology on Information Seeking Behavior of users in State Agricultural University Libraries in Karnataka. Electronic resources have changed the information seeking and retrieval method of the users. Internet is the most important and useful medium for retrieval of information from the vast information available in the globe. It is also found from the study that training programme offered by the institution are much utilized by the postgraduate students, research scholars and faculty members of the universities. It can be summarized that maximum users use e-resources for their research and educational needs. Due to ICT and availability of eresources on user's desktop, library's visit is affected to some extent, But the users visit their parent library for books/monographs and communicate with library staff through e-mail and asking help and giving suggestions as and when is required. The library professionals have great challenge to implement ICT tools and applications successfully for better utilization of print and electronic information resources.

\section{REFERENCES}

[1]. Ellis, David \& Haugan, Merete (1997). Modelling the Information-Seeking Patterns of Engineers and Research Scientists in Industrial Environment. Journal of Documentation, 53(4), 384-403.

[2]. Haneefa, K., (2007). Use of ICT based resources and services in special libraries in Kerala. Annals of Library and Information Studies, 54(1), 23-31.

[3]. Kadli, J., \& Kumbar, B.D., (2011). Faculty information seeking behavior in the changing ICT environment: a study of commerce colleges in Mumbai. Library Philosophy and Practice, 6, 1-13. Retrieved from http://digitalcommons.unl.edu /libphilprac/580/

[4]. Manikandan,G, E., Mohamed, S., and Nagarajan, M., (2013). Impact of Information Technology on Information Seeking Behavior of the Users: An Empirical Study. Journal of Advances in Library and Information Science, 2 (2), 60-64.

[5]. Shiva Krishna, S. D., \& AdithyaKumari, H., (2016). Information Seeking Behaviour in ICT Environment among Users in Karnataka State Agricultural University Libraries: A Study. International Journal of Library and Information Studies, 6 (2), 36-49. Retrieved from http://ijlis.org/img/2016_Vol_6_Issue_2/36-49.pdf. 